REVIEW PAPER

\title{
The value of long-term monitoring of the San Francisco Estuary for Delta Smelt and Longfin Smelt
}

\author{
TRISHELLE L. TEMPEL ${ }^{1 *}$, TIMOTHY D. MALINICH ${ }^{1}$, JILLIAN \\ BURNS ${ }^{1}$, ARTHUR BARROS ${ }^{1}$, CHRISTINA E. BURDI $^{1}$, AND JAMES
} A. $\mathrm{HOBBS}^{1}$

${ }^{1}$ California Department of Fish and Wildlife, Interagency Ecological Program Monitoring Program, 2109 Arch Airport Road Suite 100, Stockton, CA 95206, USA

*Corresponding Author: trishelle.tempel@wildlife.ca.gov

Key words: California Endangered Species Act, Delta Smelt, Endangered Species Act, Hypomesus transpacificus, Longfin Smelt, long term monitoring, Sacramento-San Joaquin Delta, San Francisco Estuary, Spirinchus thaleichthys

Long-term ecological studies are an important tool for understanding ecosystem change over time and can be valuable for distinguishing short-term fluctuations from long-term population trajectories (Wolfe et al. 1987; Bograd et al. 2003; Likens 2012; Lindenmayer et al. 2012; Hughes et al. 2017). Such studies are imperative to understanding the causes of population decline, such as habitat loss, harvest, invasive species, pollution, and both natural and human-caused environmental change (Kimmerer et al. 2001; Kimmerer 2002; Sommer et al. 2007; Moyle et al. 2016). In this way, long-term ecological studies are critical for providing scientific data to assess population status and make evidence-based decisions to protect and recover imperiled species. Long-term ecological studies are rare due to the logistical challenges in maintaining survey consistency, changing or lack of legal mandates, high maintenance and operational costs, and political will to continue when populations continue to decline. However, listings of species as threatened or endangered under the California Endangered Species Act (CESA) and federal Endangered Species Act (ESA) can result in legal mandates to maintain, improve, or develop long-term monitoring studies to better understand how species respond to management activities. Here we provide a historical perspective of long-term fish monitoring studies conducted in the San Francisco Estuary, their evolution in response to data and management needs, how their valuable datasets have identified multiple periods of ecosystem regime change, and their role in protecting two native osmerids, Delta Smelt (Hypomesus transpacificus) and Longfin Smelt (Spirinchus thaleichthys). Prior reviews of long-term monitoring efforts in the San Francisco Estuary have focused on individual survey effectiveness, overall management priorities, and how to improve specific survey elements (Honey et al. 2004). 


\section{THE SAN FRANCISCO ESTUARY}

The San Francisco Estuary (Estuary) is the largest estuary in the western United States. The Estuary's watershed extends from the Sierra Nevada mountains to the Golden Gate Bridge and drains an area that includes almost $40 \%$ of California ${ }^{1}$. Water primarily enters the Estuary through two major rivers, the Sacramento and San Joaquin, and their tributaries (Fig. 1). These rivers converge and drain to San Francisco Bay. The area upstream of this convergence is typically composed of fresh or slightly brackish water and is referred to as the Sacramento-San Joaquin Delta ${ }^{2}$ (Delta). Over a century ago, land management practices fundamentally changed the landscape of the Delta (SFEI-ASC 2014). The historic Delta was an expansive wetland that provided diverse and dynamic habitat types. The Delta today consists of deep channels, diked wetlands for agriculture, and levees for flood protection (SFEI-ASC 2014). Downstream of the convergence of the Sacramento and San Joaquin Rivers water enters the Suisun region, which provides low salinity and marsh habitat. Salinity in the Suisun region and the Delta tends to increase in the late summer and fall and, to a greater extent, during periods of drought. Downstream of the Suisun region, the salinity continues to increase as the water moves through San Pablo Bay and Central Bay, which connects to the Pacific Ocean. The South Bay is a shallow lobe that extends from Central Bay and receives infrequent episodic freshwater inflow from local tributaries.

The timing and amount of freshwater flow into the Estuary has substantially changed as a result of providing water for urban use to over 27-million Californians ${ }^{3}$ and irrigation for a $\$ 50$-billion-dollar agricultural industry ${ }^{4}$. Inflow to the Estuary is managed by a system of upstream reservoirs and water diversions along the rivers and within the Delta. These water conveyance systems are operated by the U.S. Bureau of Reclamation's (USBR) Central Valley Project (CVP) and the California Department of Water Resources' (DWR) State Water Project (SWP). Unimpaired flow is the inflow that would pass through the Estuary without these upstream dams and diversions and it can be drastically different from the actual inflow that reaches the Delta (SWRCB 2010). Outflow is the amount of water that passes through the Estuary and into San Francisco Bay. Most of the difference between inflow and outflow is due to two large CVP and SWP water facilities located in the southern end of the Delta, the Bill Jones Pumping Plant and the Harvey O. Banks Pumping Plant, which export a sizeable proportion of the water entering the Delta (Figs. 1 and 2). Since 1987, the volume of water exported through these facilities has ranged from 3.7-7.4 billion $\mathrm{m}^{3}$ (3-6-millon acre-feet) per year, which at times has been as much as 50\% of Delta inflow (Fig. 2c; Cloern and Jassby 2012; Hutton et al. 2017a,b). The volume of water exported by the facilities is often sufficient to reverse the net flow of the Old and Middle rivers (Fig. 1). When this occurs, fish are entrained in this backwards flow, transporting them into the pumping facilities (Arthur et al. 1996; Kimmerer 2008; Grimaldo et al. 2009; Smith et al. 2020).

\section{THE BEGINNING: MONITORING STRIPED BASS IN A CHANGING ESTUARY (1940-1970)}

The Estuary is home to a plethora of resident and anadromous fish species and has supported lucrative commercial and sport fishing industries. The CVP's Bill Jones Pumping

\footnotetext{
${ }^{1}$ https://www.sfestuary.org/our-estuary/about-the-estuary/

${ }^{2}$ https://data.cnra.ca.gov/dataset/legal-delta-boundary

${ }^{3} \mathrm{https}$ //water.ca.gov/Programs/State-Water-Project

${ }^{4}$ https://www.cdfa.ca.gov/statistics/
} 


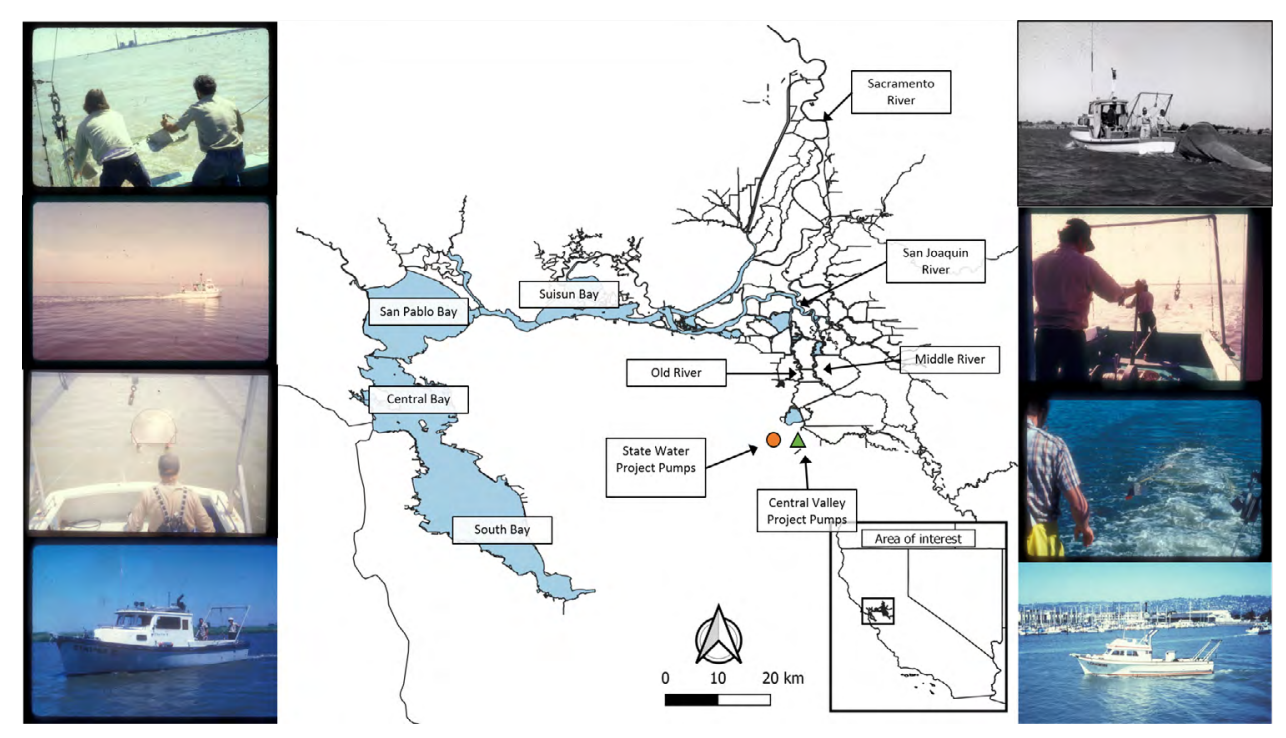

Figure 1. Map of the San Francisco Estuary, the study area encompassed by the long-term surveys, with State Water Project and Central Valley Project pumping stations denoted.

Plant was constructed from 1947-1951, and in 1950 the United States Fish and Wildlife Service (USFWS) released a report exploring the potential effects of the CVP on fishery resources in the Estuary (Erkkila et al. 1950). This report estimated that in the years prior to the CVP, the annual commercial catch of Chinook Salmon (Oncorhynchus tshawytscha) stemming from the Estuary was around 2,540,117 $\mathrm{kg}(5,600,000 \mathrm{lbs})$. In the $1940 \mathrm{~s}$, the California Striped Bass (Morone saxatilis) sport fishery produced an estimated annual catch of around 6,000,000 pounds, most of which originated in Delta waters and tributaries. The report concluded that operation of the CVP would have detrimental effects on both Chinook Salmon and Striped Bass populations. This report noted that Chinook Salmon entered the Delta from upstream spawning areas and were seasonally dominant from February to May, while Striped Bass spawned in the Delta in the spring and the largest concentration of eggs were collected in the San Joaquin River, Old River, and Middle River, highlighting the historic importance of the central and south Delta as a Striped Bass nursery. Striped Bass eggs are pelagic, so both eggs and larvae are particularly vulnerable to flow. Juvenile Striped Bass were seasonally dominant from June through September, aligning with the projected period of peak CVP demands. Recommendations were made to divert fish from the intake into a collection facility, and to conduct additional studies to better understand the ecology of the system, the effects of an altered environment, and how to protect fish (Erkkila et al. 1950). In this vein, the Bill Jones Pumping Plant was equipped with a louvre system to direct fish into the Tracy Fish Collection Facility, where fish are counted, placed in transport trucks, and returned to the Delta. The louvres rely on behavioral changes in fish swimming to direct fish into the fish facility, therefore passive organisms such as eggs and larval fish generally move past the louvre system uncounted, along with a fraction of juveniles and adults of some species (Brown et al. 1996; Morinaka 2013). The Tracy Fish Collection Facility has been salvaging fish since 1957 and is considered the oldest long-term monitoring program in the Estuary. 

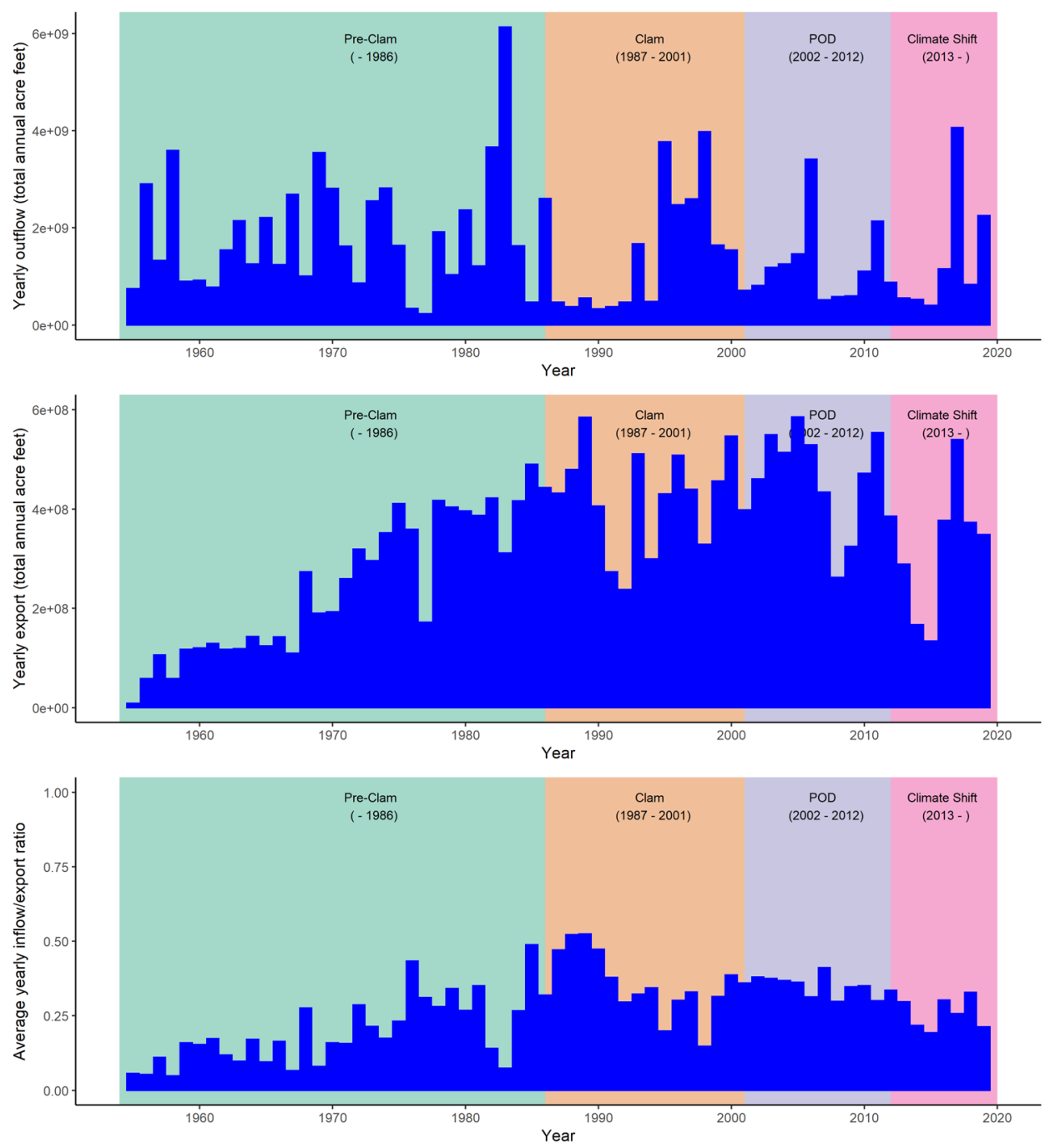

Figure 2. Daily outflow and export (acre feet/second) within the Delta region. Daily estimates from the Department of Water Resources Dayflow (https://water.ca.gov/Programs/Environmental-Services/Compliance-MonitoringAnd-Assessment/Dayflow-Data).

Further development of the water conveyance system continued through the 1950s and 1960s. During this time, DWR supported an unmandated contract with the California Department of Fish and Game (CDFG, now the California Department of Fish and Wildlife, CDFW) to monitor and develop information needed to support water project construction (Herrgesell 2012). One such study, the Summer Townet Survey (STN) ${ }^{5}$, was initiated in 1959 to sample juvenile life stages of pelagic fish from June through August and provide an index of Striped Bass recruitment. The water bond passed the legislature in 1961, which led to

${ }^{5} \mathrm{https} / / /$ wildlife.ca.gov/Conservation/Delta/Townet-Survey 
contracted joint studies between CDFW and DWR. The objectives of these studies were to investigate the effects of the Delta Water Project on fish and wildlife resources, and to make recommendations on project plans and means of compensation for fish losses. Importantly, the plans called for coordination with other interested Federal, State, and local agencies. This partnership, and funding for monitoring, became further cemented in legislation with the 1963 Davis-Dolwig Act, which mandated close coordination between DWR, CDFW, and other appropriate agencies for the preservation and enhancement of fish and wildlife (Herrgesell 2012). This laid the groundwork for the 1967 initiation of the Fall Midwater Trawl Survey (FMWT) ${ }^{6}$, which samples sub-adult life stages of pelagic fish from September through December, and the Egg and Larval Survey, which was used to describe patterns in Striped Bass hatching and rearing. The STN, FMWT, and Egg and Larval Survey conducted pelagic trawls that primarily focused on the legal Delta and downstream into San Pablo Bay (Fig. 3; Turner and Chadwick 1972; Chadwick et al. 1977; Stevens et al. 1985). Since their inception, these surveys have collected data on all fish species collected, in line with recommendations to better understand the ecosystem. The Egg and Larval Survey ceased in 1994, but the STN and FMWT continue to this day. Over time, these early coordination efforts gave rise to the legislative basis and formation of the Interagency Ecological Program (IEP), a multi-agency consortium that to this day continues to provide, integrate, and analyze data pertaining to the Estuary and the water that flows through it. Construction of a second large pumping facility in the southern Delta, the SWP's Harvey O. Banks Pumping Plant, was completed in 1969 and upgraded to increase capacity in 1987. Similar to operations at the CVP, a louvre system is used to direct fish from the intake to the Skinner Delta Fish Protective Facility, which has been salvaging fish since 1968. CDFW works with USBR and DWR to conduct sampling of entrained fish at these facilities and provide loss estimates ${ }^{7}$. The fish facilities have undergone numerous changes over the years, many to improve the salvage of listed salmonids. Salvaged fish have been routinely identified to species since July 1992 (Brown et al. 1996; Morinaka 2013). Delta Smelt salvage data was collected prior to July 1992 but is considered less reliable than data collected after this date (IEP MAST 2015).

\section{DECLINES, DROUGHTS, AND LEGISLATION: SHIFTING FOCUS TO DELTA SMELT AND LONGFIN SMELT (1970-1990)}

The California Endangered Species Act (CESA) was signed into law in 1970, and the federal Endangered Species Act (ESA) was signed into law in 1973. These laws provide legal backing to protect and recover species at risk of extinction. In the Estuary, these laws set the legal framework for protecting species in decline, independent of their economic value. This framework slowly started to shift the analytic goals of long terms monitoring datasets in the Estuary. The fact that the STN and FMWT collected data on all species encountered was critical to the continuation of these programs as management needs changed. In 1980, the San Francisco Bay Study (BS) ${ }^{8}$ was initiated with the thought that reduced-outflow effects could be occurring downstream of the Delta and influencing organism populations in ways beyond direct entrainment. The BS conducts monthly surveys year-round to facilitate our understanding of the effects of reduced freshwater flow on pelagic and demersal fish and

\footnotetext{
${ }^{6} \mathrm{https} / /$ wildlife.ca.gov/Conservation/Delta/Fall-Midwater-Trawl

${ }^{7} \mathrm{https} / / /$ wildlife.ca.gov/Conservation/Delta/Salvage-Monitoring

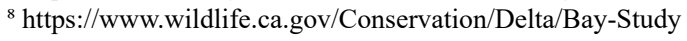




\section{Sampling Stations}
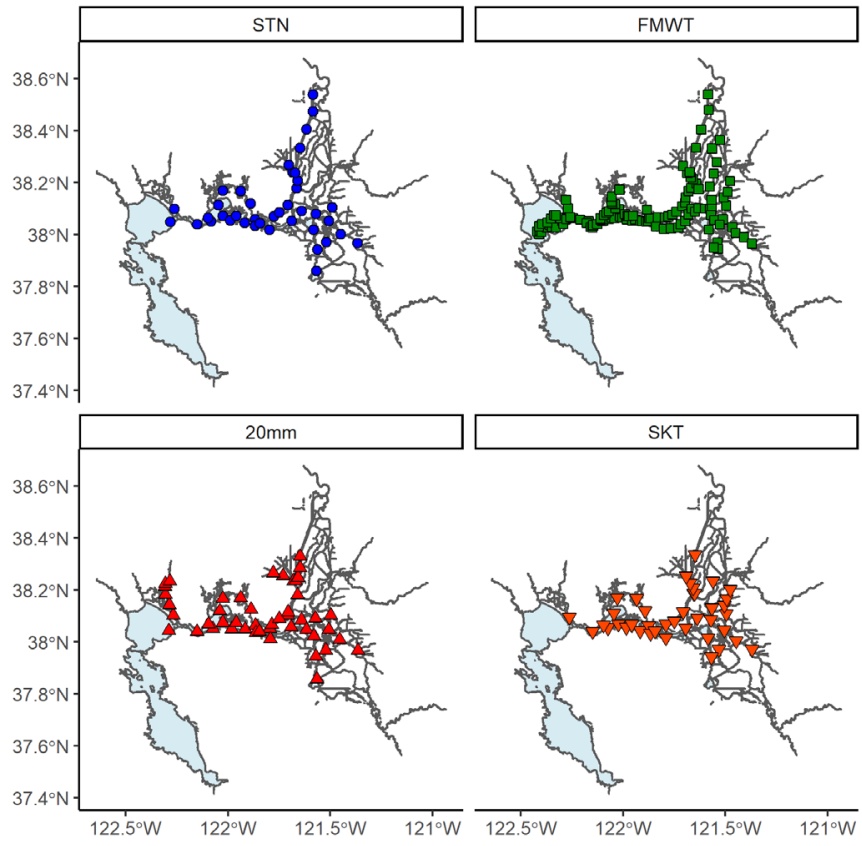
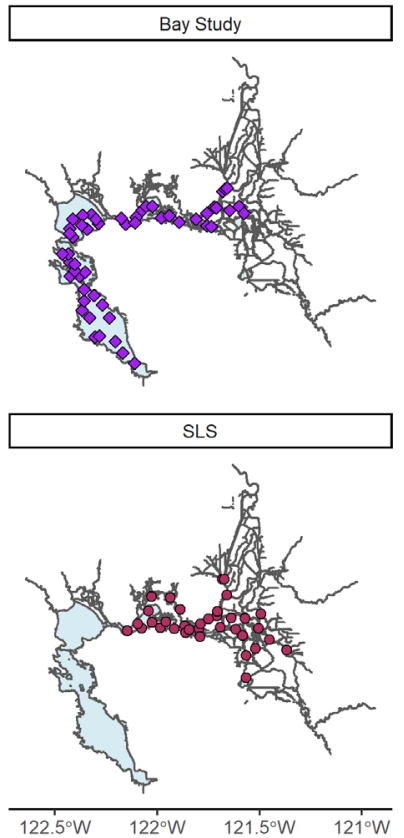

Figure 3. The six long-term surveys detailing sampling stations in the San Francisco Estuary.

mobile crustaceans. This survey extends through the Delta and downstream into San Pablo Bay, Central Bay, and South Bay. The BS currently uses two sampling gears: a demersal otter trawl (OT) and pelagic midwater trawl (MWT) to target different habitats and generate catch and associated environmental data to evaluate population changes based on outflow, which is used to inform water board decisions. Data from the STN, FMWT, and BS monitoring programs are used to produce annual indices of relative abundance for multiple species (Table 1). These calculated abundance indices were not designed to produce population estimates, but they do provide a repeatable, consistent measure of population trends over time (USFWS 1993). The resulting trends in the abundance indices highlighted the precipitous decline of two native fish species: Delta Smelt and Longfin Smelt; (Fig. 4a-c, Fig. 5a-c).

Delta Smelt were historically one of the most common pelagic species in the upper San Francisco Estuary (Erkkila et al. 1950). They are small $(<100 \mathrm{~mm})$ euryhaline pelagic fish that are endemic to the upper Estuary and were first described in 1963 (McAllister 1963). Delta Smelt are primarily an annual species, although some individuals live a second year (Moyle et al. 1992). Historically, Longfin Smelt were even more abundant and more widely distributed throughout the Estuary (Rosenfield and Baxter 2007). Longfin Smelt are slightly larger $(<150 \mathrm{~mm})$ than Delta Smelt, live two to three years, and utilize a wider range of salinity with a distribution from the San Francisco Estuary to Alaska (Moyle 2002). The abundance of Delta Smelt in the STN and FMWT precipitously declined in 1979 and 1981 respectively (Fig. 4a-b; Sweetnam and Stevens 1993; USFWS 1993). This coincides with an unusually high salvage event of Delta Smelt adults and juveniles in 1981 (IEP MAST 2015). Longfin Smelt exhibited strong year-classes in 1967 and 1969 before declining to 


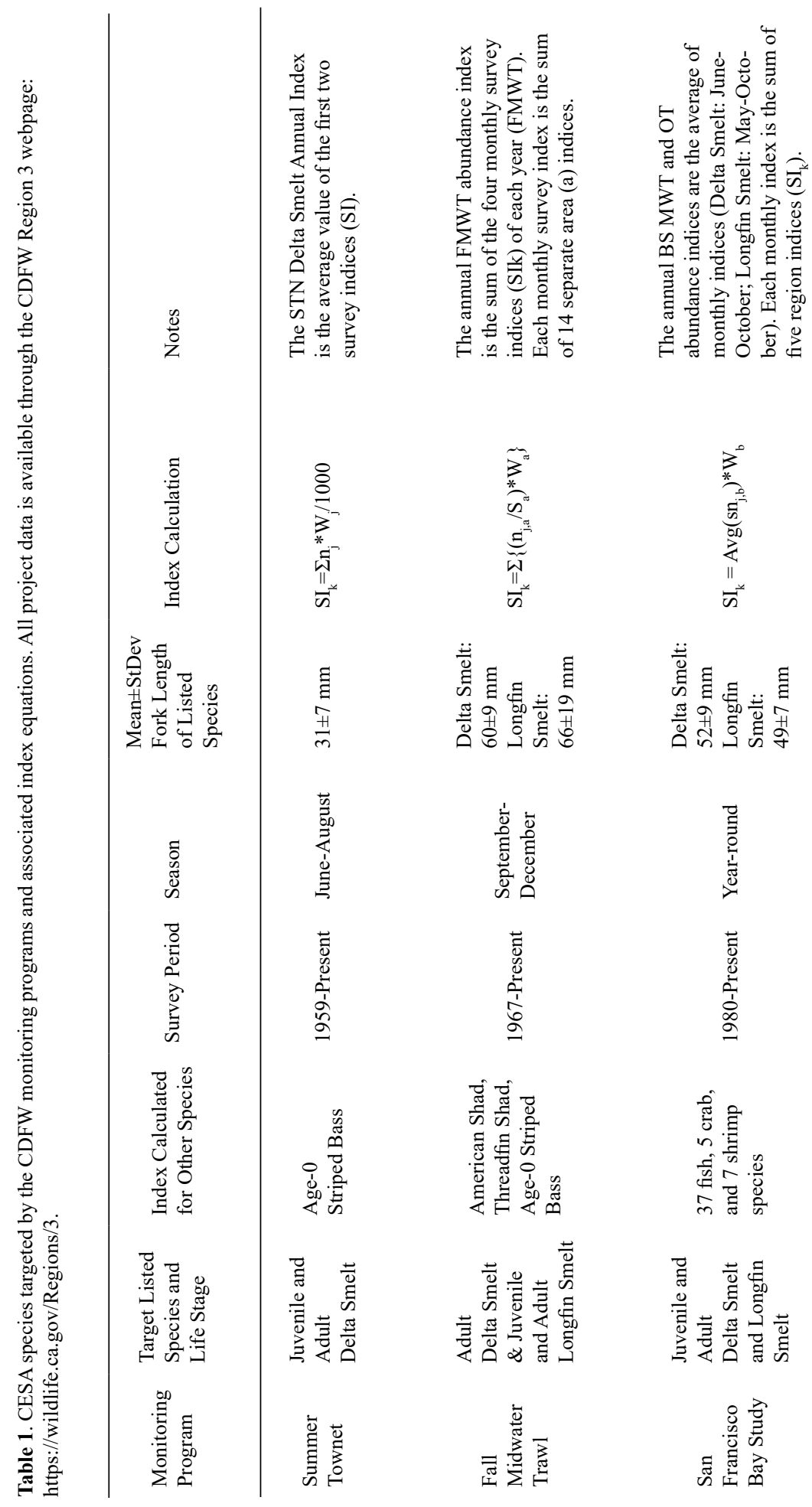




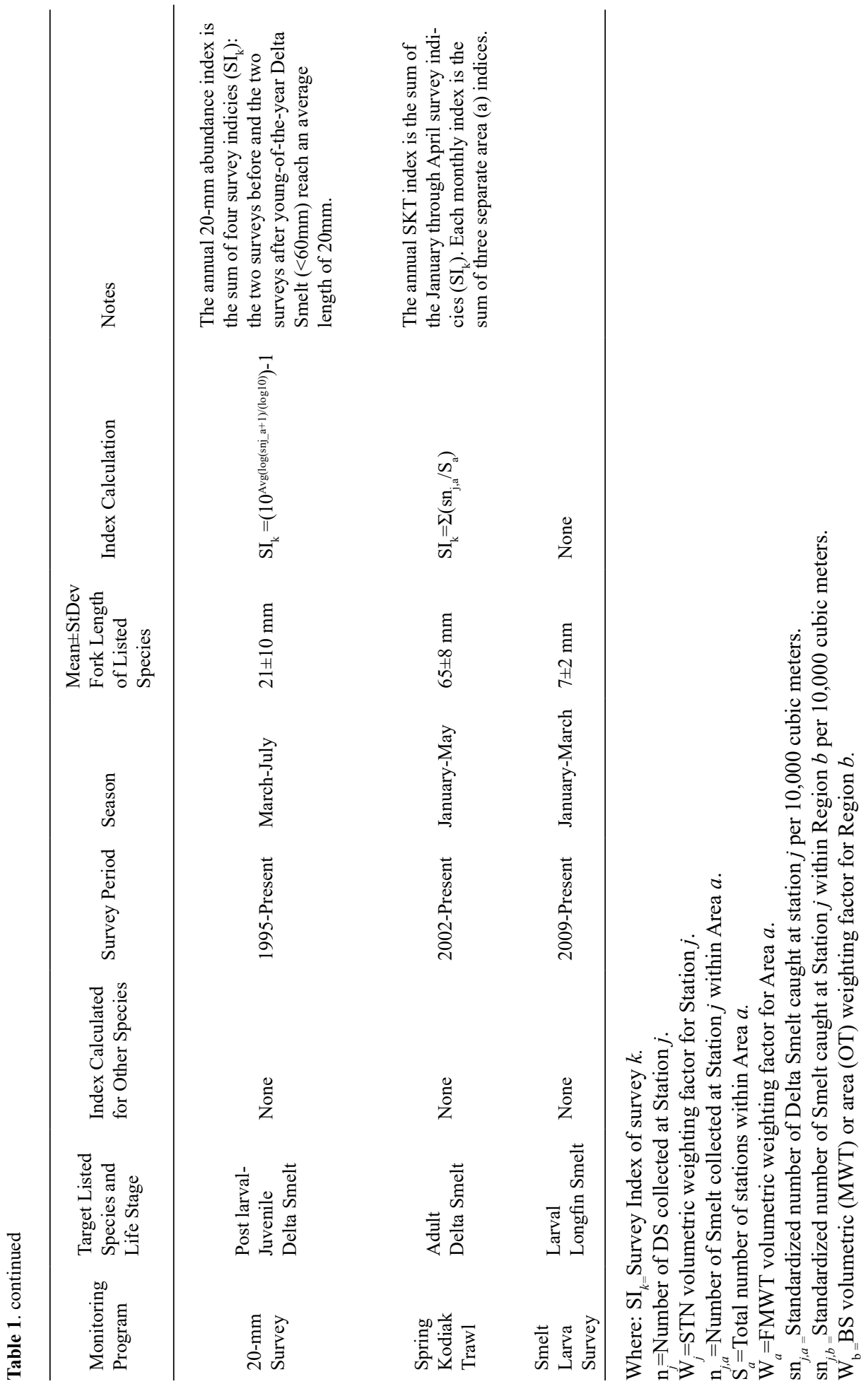




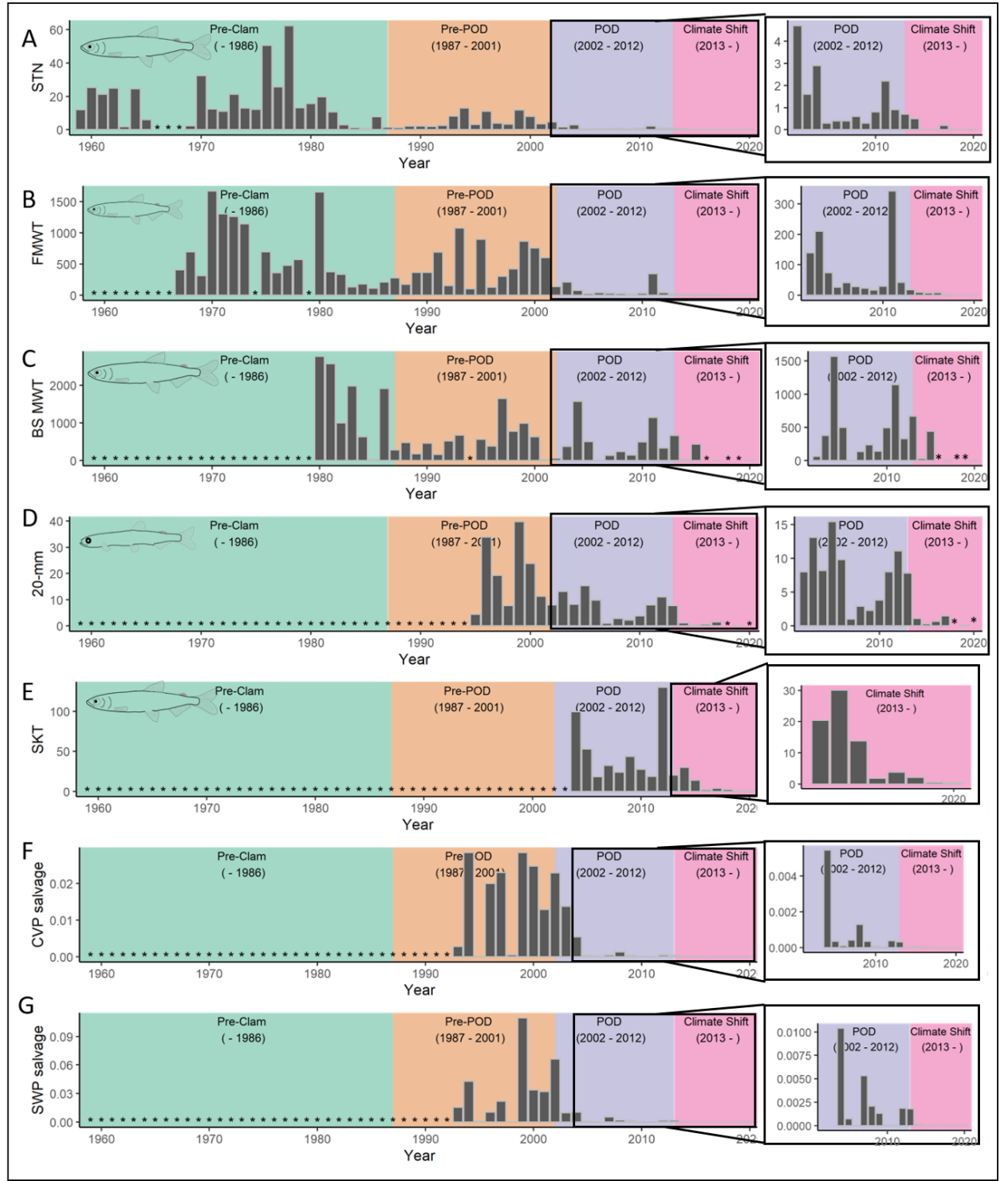

Figure 4. Delta Smelt annual abundance indices for long-term surveys as well as the SWP and CVP pump salvages (calculated in catch per acre foot). Years in which no index value could be calculated are noted with an asterisk.

low numbers through 1979, then bouncing back in 1980 and 1982 in the FMWT (Fig. 5a). The population abundance of both species remained low through the prolonged drought from 1987-1992.

During the 1987 drought, the overbite clam (Potamocorbula amurensis) was unintentionally introduced, likely from ship ballast water, and quickly became the most abundant benthic filter feeding invertebrate in the upper Estuary (Kimmerer et al. 1994). The overbite clam is a voracious consumer of phytoplankton and early instar zooplankton and has led to 


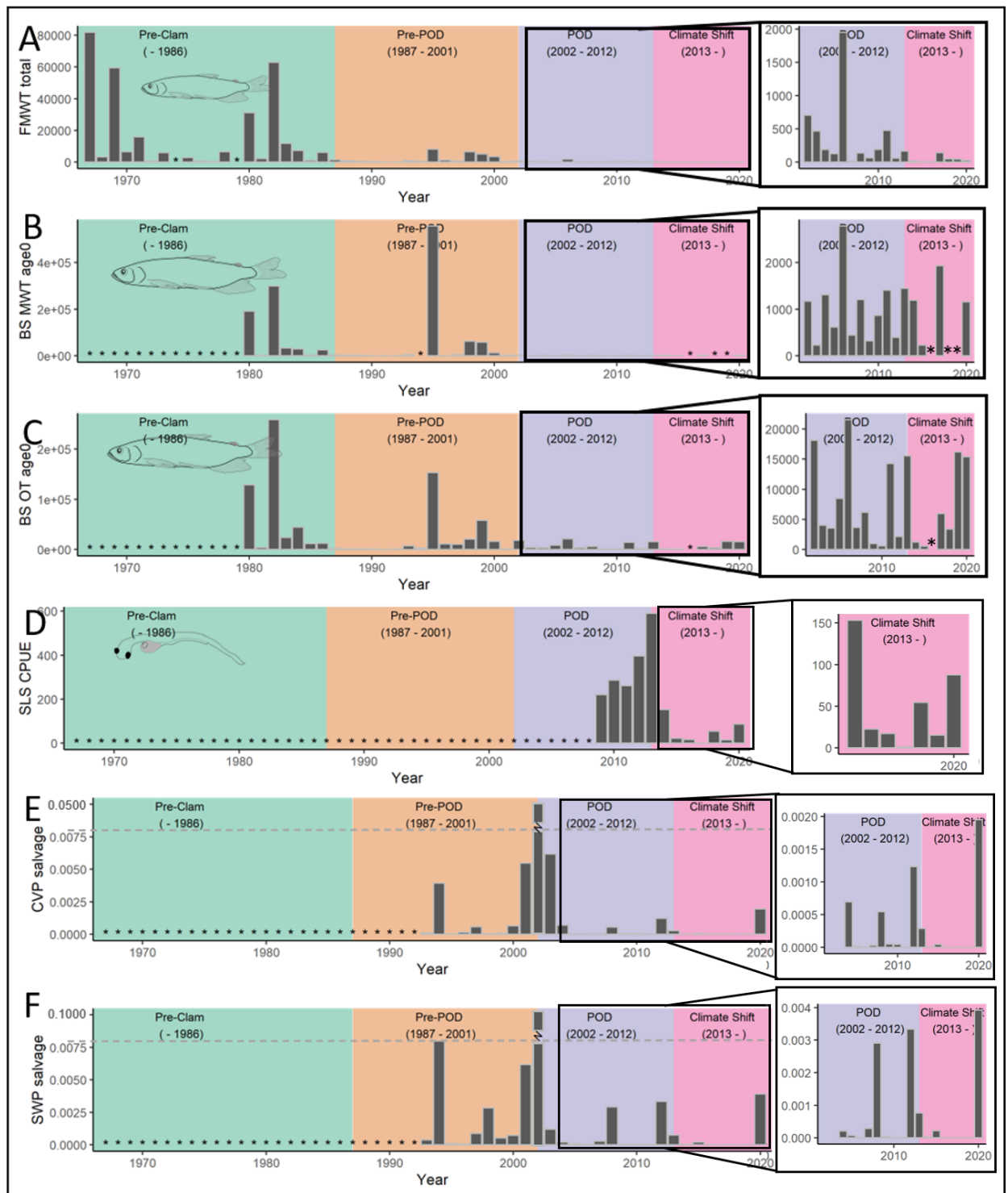

Figure 5. Longfin Smelt annual abundance indices for long-term surveys as well as the SLS catch per $1,000 \mathrm{~m}^{3}$ and the SWP and CVP pump salvages (calculated in catch per acre foot). Years in which no index value could be calculated are noted with an asterisk.

reduced food abundance for smelt and other fishes in the low-salinity region of the upper Estuary (Feyrer et al. 2003; Winder and Jassby 2011). The onset of drought and the introduction of the overbite clam marks the first regime shift observed since the initiation of monitoring, where a change in the fundamental dynamics of the ecosystem likely occurred that reduced the carrying capacity (Mac Nally et. al. 2014; Brown et al. 2016). The regime shift was driven by the clam invasion and facilitated by the drought, but other factors likely contributed such as ammonia loading, and changes in water inflows and exports (Brown et 
al. 2016). This regime shift was only identified when the abundance indices (calculated by STN, FMWT, and BS monitoring data) of species that recruit in the upper Estuary failed to regularly reach pre-clam levels (Kimmerer 2009; Figs. 4a-c, 5a-c).

In response to the observed declines in common Delta fish species, the United States Fish and Wildlife Service (USFWS) initiated status assessments in 1987 for the federal listing of Delta Smelt while CDFW conducted status assessments to inform the Fish and Game Commission on the state listing: one in 1990 (Stevens et al. 1990) which resulted in multi- agency coordination on a targeted Delta Smelt study, and one in 1993 (Sweetnam and Stevens 1993) which incorporated the results of that targeted study. CDFW found that the listing of Delta Smelt was warranted, and the population declines detected in the long-term monitoring data sets were pivotal in this finding (Sweetnam and Stevens 1993). Subsequently, Delta Smelt was listed as a threatened species under FESA on March 5, 1993 and under CESA on December 9, 1993. Reduced freshwater flows into the estuary were identified as one of the primary causes of decline (Moyle et al. 1992; USFWS 1993). Reduced inflows were associated with lower zooplankton production and retention of larvae and juveniles in the deep and narrow channels in the confluence region of the Sacramento and San Joaquin rivers, presumed to be poor habitat for many species of fish (USFWS 1995). A secondary cause was the loss of individuals by entrainment into small agricultural diversions within the Delta and by the large pumps of the SWP and CVP in the south Delta (Moyle et al. 1992). In addition, the decline was attributed to direct (toxicity to fish) and indirect (toxicity to food web) effects from changing contaminant types and loads in the Delta and Estuary (Moyle et al. 1992; Sweetnam and Stevens 1993; USFWS 1996).

\section{ADAPTIVE MANAGEMENT: LISTINGS LEAD TO NEW MONITORING PROGRAMS (1990-2000)}

As required by the federal listing of Delta Smelt, the USFWS released a series of Biological Opinions (BO) regarding the effects of CVP and SWP operations on Delta Smelt and Delta Smelt critical habitat, two of which were intended to each last one year. The 1993 BO implemented flow criteria proposed by USBR and DWR. The 1994 BO continued to implement these export reductions and incorporated Delta Smelt distribution data collected by the monitoring programs to aid in real-time water management decisions. Ongoing studies conducted by the IEP, including the CDFW long-term monitoring studies, were used to assess the effects of the 1993 and 1994 operations (USFWS 1995). In 1994, the State of California and the Federal Government agreed, through the "Principles of Agreement", to comply with a set of Bay-Delta standards intended to "provide ecosystem protection for the Bay-Delta Estuary". These standards were outlined in a draft Water Quality Control Plan released by the State Water Resources Control Board (SWRCB) (USFWS 1995). The 1995 BO stated that combined CVP and SWP operations, modified per the Principles of Agreement, draft Water Quality Control Plan, and winter-run Chinook Salmon BO, were not likely to jeopardize the continued existence of Delta Smelt (USFWS 1995). In 1999, the SWRCB released Water Right Decision 1641, which stated that the SWRCB is to be informed of impacts on fisheries relative to outflow and exports, assigned responsible parties to help meet the objectives of the 1995 Bay-Delta plan, and stated that ongoing monitoring activities recommended by CDFW, USFWS, and the National Marine Fisheries Service (NMFS) should continue (SWRCB 1999). These legal documents largely regulated protective actions for Delta Smelt in the following years. 
The California Water Policy Council and the Federal Ecosystem Directorate (together as "CALFED") were tasked with deciding how to implement these protective measures. One component of the CALFED process was the formation of an interagency Delta Smelt Working Group, who was tasked with regularly evaluating biological data and developing recommendations for protective actions. To aid in developing these recommendations, the $1995 \mathrm{BO}$ called for the continuation of CDFW monitoring programs and required the establishment of a new monitoring program to assess larval Delta Smelt abundance and distribution in the north Delta (USFWS 1995). In 1996, the USFWS released the Recovery Plan for Sacramento-San Joaquin Delta Native Fishes (USFWS 1996). The intent of the recovery plan was to outline reasonable actions that were deemed necessary to protect the Delta ecosystem, with the ultimate goal of delisting Delta Smelt and restoring populations of other species in decline. In part, the plan called for an increase in monitoring, specifically to better understand Delta Smelt, and designated CDFW, CVP, and SWP as the responsible parties. The plan also contained objectives and criteria to measure recovery using catch data from FMWT (USFWS 1996). This plan, and the FMWT recovery criteria, are still in effect today.

The 1995 BO and the 1996 Recovery Plan led to the development of three new CDFW monitoring programs designed to specifically target larval, post-larval, and spawning adult Delta Smelt. In 1995 the Egg and Larval Survey, transitioned from targeting Striped Bass to targeting Delta Smelt, and became the North Bay Aqueduct Larval Fish Survey ${ }^{9}$. The new survey design monitored the abundance and distribution of larval Delta Smelt in the North Delta, where spawning was thought to occur, and evaluated larval entrainment to a pumping facility in Barker Slough, also in the North Delta. The $20-\mathrm{mm}$ Survey ${ }^{10}$ was initiated in 1995 to track the distribution and abundance of post-larval and juvenile life stages and was used as a real-time tool to inform daily CVP and SWP operations from March to July (Fig. 3). The gear was designed to fully retain a Delta Smelt $20 \mathrm{~mm}$ in size (Mitchell et al. 2019), which is the size when Delta Smelt have an inflated air bladder and are retained and readily identifiable at the fish salvage facilities associated with the SWP and CVP. To track the distribution of adult Delta Smelt and assist with water management decisions, beginning in 1991 an extension of the FMWT sampled into the spring, January-March (Spring Midwater Trawl). Net evaluation studies conducted in 1995 found that a Kodiak trawl net, which is towed at the surface between two vessels, was the most effective gear for detecting and retaining adult Delta Smelt; thus, in 2002 the springtime sampling gear was changed from an obliquely towed midwater trawl net to a surface towed Kodiak net and became the Spring Kodiak Trawl Survey (SKT) ${ }^{11}$ (Sweetnam 1994; CDFG unpublished data; Souza 2002). The SKT samples throughout the spawning season (January-May) to determine the distribution and abundance of adult Delta Smelt. In addition, each Delta Smelt is dissected in the field and examined for gonadal development to identify and rapidly report the onset of spawning. Until 2008, when take became a greater concern, supplemental SKT sampling targeted regions believed to support Delta Smelt spawning habitat to enhance the understanding of maturity status. The $20-\mathrm{mm}$ Survey and the SKT both calculate indices of relative abundance for different life stages of Delta Smelt (Fig. 4d-e). Both surveys were designed to monitor population trends of Delta Smelt, and these trends mirror those observed in STN and FMWT, but neither survey was designed to produce a population

\footnotetext{
${ }^{9}$ https://wildlife.ca.gov/Conservation/Delta/North-Bay-Aqueduct

${ }^{10} \mathrm{https}$ //www.wildlife.ca.gov/Conservation/Delta/20mm-Survey

${ }^{11} \mathrm{https}$ //www.wildlife.ca.gov/Conservation/Delta/Spring-Kodiak-Trawl
} 
estimate. When aligned with STN and FMWT, these four monitoring programs track the abundance and distribution of critical points in the Delta Smelt lifecycle (Table 1). This combination of new and long-standing monitoring programs enabled decision makers to assess the real-time risk water operations posed to the species, and enabled researchers to gain a deeper understanding of each life stage and track the success of recovery actions by continuing to monitor population trends over time

\section{THE PELAGIC ORGANISM DECLINE: DETECTING AND ADAPTING TO A NEW NORMAL (2000-2005)}

The Delta Smelt indices (Fig. 4a-e), and Longfin Smelt indices (Fig. 5a-c) showed a further decline beginning in the early 2000s along with a decline in other pelagic fishes; by 2004 this broader phenomenon was recognized as the Pelagic Organism Decline (POD; Sommer et al. 2007; Thomson et al. 2010). The POD marks the second regime shift, where, again, monitoring data showed a step-decline in Delta Smelt and Longfin Smelt abundance indices in the upper estuary. This decline was likely the result of another reduction in carrying capacity, despite some management actions already in place to protect Delta Smelt. This led to numerous studies attempting to identify the cause of the POD to improve future management. No one factor was identified, but many biotic and abiotic factors could have had a synergistic effect, including, but not limited to, an upstream shift of the low salinity zone, water exports, increased water clarity, and declines in prey availability (Sommer et al. 2007; McNally et al. 2010; Thomson et al. 2010). Additionally, Delta Smelt and Longfin Smelt salvage (individuals per acre-foot of water) was highest leading up to the POD regime (Figs. 4f-g and 5e-f). Recent modeling efforts indicate that since the 1993 listing of Delta Smelt, the highest levels of adult and post-larval entrainment occurred between 2000 and 2004, coinciding with the onset of the POD (Smith 2019; Smith et al. 2020).

In response to the POD, monitoring efforts continued to increase for Delta Smelt and Longfin Smelt, and modifications to existing surveys were implemented to increase knowledge of each species' ecology. For example, in 2005 the STN and FMWT began collecting meso-zooplankton samples, and FMWT also began collecting mysid samples, to examine potential food limitation for fish and habitat productivity. Pelagic fish collected by all monitoring programs were retained for diet and condition studies, and Delta Smelt were analyzed for condition, growth, life history diversity, and health (e.g., Hammock et al. 2015; Hobbs et al. 2019; Teh et al. 2020). Additionally, in 2005 the North Bay Aqueduct Larval Fish Survey transformed into the Delta Smelt Larval Survey, which expanded larval monitoring to assess the abundance and distribution of larval Delta Smelt in the upper Estuary, entrainment risk at CVP and SWP, and investigated catch efficiencies at different portions of the water column.

\section{CONTINUING TO ADAPT: NEW RULES, DEEPER DECLINES (2005-PRESENT)}

In 2005, the State of California Resources Agency, DWR, and CDFW developed the Delta Smelt Action Plan to identify a 14-point program to address the decline in fish and zooplankton populations (California Resources Agency 2005). Shortly after the release of this plan, the California legislature directed the California Resources Agency to report on proposed actions to address the POD and stabilize the estuary ecosystem (California Re- 
sources Agency 2007). This described a suite of ongoing and new actions, with coordination and funding among State and Federal agencies, to pursue flow management, habitat restoration, and monitoring activities, with DWR and CDFW continuing to take steps to address the decline of pelagic organisms. The decline in both species during the POD led to petitions to up-list Delta Smelt from threatened to endangered under CESA and FESA and re-evaluate the status of Longfin Smelt for listing under CESA and FESA. The status review for Delta Smelt highlighted the fact that index values from STN and FMWT were persistently low in the 2000s, "despite sometimes-favorable springtime environmental conditions and intensive management efforts attributable in part to prior endangered species act listings (CDFG 2008)." As a result, Delta Smelt was up-listed from threatened to endangered under CESA on March $4^{\text {th }}, 2009$, but was found warranted-but-precluded from federal up-listing. To date, Delta Smelt remain federally threatened (USFWS 2010). Longfin Smelt was added to CESA as threatened on March 5 ${ }^{\text {th }}, 2009$ based on their continued decline, despite some years of beneficial freshwater outflows (CDFG 2009). The review leading to the listing pointed to water diversion operations (e.g., entrainment and mortality at export facilities and habitat modifications related to salinity), invasive species impacts to prey availability, water pollution, predators, a commercial bait fishery, and scientific collections as threats to the Longfin Smelt population (CDFG 2009). Meanwhile USFWS found Longfin Smelt was not warranted for federal listing at the time (USFWS 2009); however, in 2012 the USFWS found that the federal listing of the Bay-Delta distinct population segment of Longfin Smelt was warranted for listing, but, as in the case of Delta Smelt, it was precluded by higher priority actions (USFWS 2012).

The continued decline of both species under favorable conditions during some seasons or in some years indicated the need for additional information to inform future management actions. Therefore, following the 2008 up-listing of Delta Smelt and 2009 listing of Longfin Smelt under CESA, additional sampling sites were added in the North Delta to the STN (8 stations added in 2011; Contreras et al. 2011), FMWT (6 stations added in 2009 and 2010), and 20-mm (6 stations added in 2008) monitoring programs to better capture potential Delta Smelt habitat. This importance of this region was discovered when adults in spawning condition were regularly collected in the North Delta during supplemental SKT surveys from years prior. To maintain comparability through time, catch from these sites is not incorporated in the annual index calculations, but the data is included in the annual indices reports, and abundance trends at North Delta sites are similar to abundance trends at historic sites (Tempel 2017; White and Baxter, in review). In 2009 the Delta Smelt Larval Survey was transformed into the Smelt Larva Survey (SLS) ${ }^{12}$ to monitor the distribution of larval Longfin Smelt in the upper Estuary. This survey targets small larvae $(<11 \mathrm{~mm}$ in length), samples from January through March, and was designed to provide near-real-time distribution data for agency managers to assess the risk of entrainment to larval Longfin Smelt at the CVP and SWP. Unlike the other monitoring programs, abundance indices are not calculated using SLS data because the survey focuses sampling to the upper Estuary to directly inform entrainment risk and is unlikely to capture the center of distribution of Longfin Smelt larvae in wetter years, which shifts downstream into San Pablo Bay and the South Bay (Baxter 1999; Lewis et al. 2020; Grimaldo et al. 2020).

Legally, the FESA and CESA listings implemented additional requirements to continue operations at the CVP and SWP. In 2008, the USFWS released a Biological Opinion (BO)

\footnotetext{
${ }^{12}$ https://wildlife.ca.gov/Conservation/Delta/Smelt-Larva-Survey
} 
on the Long-Term Operational Criteria and Plan (OCAP) for the coordinated operation of the CVP and SWP, which determined that continued operation of the water projects was likely to jeopardize the continued existence of Delta Smelt and adversely modify critical habitat. To minimize the effects of water operations, a series of alternative actions were established, termed Reasonable and Prudent Alternatives (RPA's). These RPA's implemented restrictions on exports at SWP and CVP by managing negative flows through Old and Middle River (OMR; Fig. 1), the main pathway leading to the South Delta pumping facilities, to protect adult Delta Smelt during spawning migrations and larvae-juveniles while hatching and rearing in the Delta. The RPA's also targeted improvements to habitat conditions for growth and rearing of sub-adult Delta Smelt by increasing Delta outflow in fall and called for intertidal and subtidal habitat restoration in the Delta and Suisun Marsh. In 2009, along with listing Longfin Smelt, CDFW issued an Incidental Take Permit (ITP) for Longfin Smelt to DWR, authorizing continued operations of the SWP (CDFG 2009). The ITP implemented restrictions on OMR flows to minimize entrainment of adult and larval Longfin Smelt during the spawning and rearing period, improve downstream transport of larvae, and increase Longfin Smelt habitat quality and quantity (CDFG 2009). The BO and ITP required the SLS, 20-mm Survey, and SKT to provide real-time distribution data, and required the calculation of FMWT indices to set salvage limits. To evaluate any necessary export restrictions, the Smelt Working Group (SWG) ${ }^{13}$, which consisted of experts in Delta Smelt and Longfin Smelt biology from the USFWS, USBR, U.S. Environmental Protection Agency, California Department of Natural Resources, DWR, NOAA Fisheries, and CDFW, was tasked with convening on a weekly basis from December through June to evaluate data on catch patterns, flow, turbidity, salvage, and other parameters, to assess the distribution of smelt in the Delta and predict the timing of their movements, and to provide an entrainment risk assessment of different life stages at varying levels of negative Old and Middle River flow. Based on these data, the SWG sent OMR flow recommendations to the USFWS (for Delta Smelt) or CDFW (for Longfin Smelt) to minimize risk of smelt entrainment. The USFWS or CDFW would then report their final decision to the Water Operations Management Team (WOMT). Reis et al. (2019) investigated the effects of these environmental regulations on water exports and found that Delta Smelt RPA's limited exports on only 8\% of days from 2011 through 2018 ( 275 days total). Of these reductions, 4\% of days were constrained to meet Fall X2 requirements, $4 \%$ of days were constrained to meet OMR flow recommendations, and an additional $2 \%$ of days were voluntary reductions that may have been implemented to avoid excessive take. When Delta Smelt salvage is standardized to the FMWT index (sum of adult and juvenile salvage/FMWT), the standard value has been relatively low since 2009 (Moyle et al. 2016). Furthermore, Smith et al. (2020), using advanced modelling techniques, found far reduced post-larval entrainment since 2004. This indicates that flow management in the POD regime had been successful at reducing entrainment, however; the observed low levels of entrainment could also reflect the declining population (Blumenshine et al. 2000).

The 2008 BO required DWR and USBR to provide sufficient Delta outflow to maintain monthly average X2 (the 2 parts per thousand salinity isohaline as measured in kilometers upstream of the Golden Gate Bridge) no greater than $74 \mathrm{~km}$ in wet years and no greater than $81 \mathrm{~km}$ in normal years for the months of September and October. In addition, in wet or above normal years all inflow to SWP and CVP reservoirs in November would be released to provide additional outflow from the Delta to augment the fall flow Action (USFWS 2008).

\footnotetext{
${ }^{13} \mathrm{https}: / /$ www.fws.gov/sfbaydelta/cvp-swp/smelt_working_group.cfm
} 
The intent of these actions was to expand and improve Delta Smelt habitat and potentially increase productivity. Criteria for the fall flow actions were easily achieved in 2011 due to high flows from early rains and ample reservoir storage. The 2011 FMWT abundance index for Delta Smelt increased substantially relative to all previous years since the POD signaling this management action was successful (Fig. 4b; Brown et al. 2014; FLOAT-MAST 2020). The criteria for the fall flow actions were also met in 2017 and 2019, but less wet conditions, and the drought years preceding the 2017 action, resulted in low summer flows and an early end to the actions in order to maintain reservoir storage. The FMWT Delta Smelt index did not substantially increase due to the 2017 or 2019 action (Fig. 4b; Brown et al. 2014; FLOAT-MAST 2020). High flows in 2011, 2017, and 2019 may have also contributed to moderate increases in the FMWT Longfin Smelt index (Fig. 5a).

Following the 2008 BO, the 2009 ITP, and the wet year of 2011 and corresponding implementation of the fall flow action, several long-term monitoring programs observed increases in many of the 2010 and 2011 Delta Smelt and Longfin Smelt indices (Figs. 4a-e and 5a-c). Unfortunately, an extensive drought period began in 2012; habitat conditions began to decline further, and the abundance indices of both smelt species plummeted to record lows and have not recovered (Figs. 4a-e and 5a-c). This period may mark the most recent regime shift, and notably brings Delta Smelt to the brink of detection limits of the long-term monitoring programs (Fig. 4). As with the previous regime changes, the drop in abundance indices were likely driven by multiple stressors including low food resources (Sommer et al. 2007; Winder and Jassby 2011; Moyle et al. 2016), a climatic shift toward warmer temperatures and lower flows (Brown et al. 2013, Castillo et al. 2018; Fig. 2), and an already diminished population following the POD (Thomson et al. 2010). This most recent climate shift period (2013-present) for Delta Smelt is marked by an abrupt drop in abundance indices (Fig. 4). Both the minor increase and steep decline in Delta Smelt indices were observed across all life stages. The depth of this decline is marked by the first recorded zero-index by STN in 2015, followed by FMWT's first zero-index in 2018 (Fig. 4a-b). Notably, all index values showed a very minimal response to the wet years of 2017 and 2019, suggesting the population was unable to rebound following improved flow conditions; however, high summer and fall temperatures in those years may have prevented a rebound (FLOAT-MAST 2020). Motivated by the $2008 \mathrm{BO}$ and the continued decline of Delta Smelt, in 2011 USBR and the IEP began a large-scale synthesis study that incorporated long-term monitoring data to explore the importance of fall low-salinity habitat ("FLASH") for Delta Smelt (Brown et al. 2014). The report found interpretation of Delta Smelt response was difficult to explain without context of preceding conditions. IEP responded with an analysis inclusive of the entire life cycle, applying a 4-season approach to update conceptual models of factors affecting Delta Smelt (IEP MAST 2015). The results of the MAST would inform further actions. In 2016, the California Natural Resources Agency published the Delta Smelt Resiliency Strategy ${ }^{14}$ that outlined a suite of actions intended to benefit Delta Smelt, including, but not limited to, promoting food production, augmenting outflow in the summer of 2016 and spring and summer of 2017 and 2018, and restoring habitat; some of these measures, including Delta Smelt response, were to be evaluated by the long-term monitoring data. The final regime for Longfin Smelt is marked by declines in the FMWT index and SLS catch-per-unit-effort (CPUE), which suggests that the current regime shift may have negatively impacted upstream habitat for Longfin Smelt use (Fig. 5).

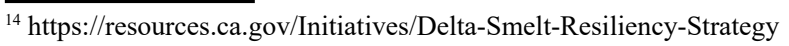




\section{LOOKING FORWARD: A DELTA DIVIDED}

In 2016, USBR and DWR requested the Reinitiation of Consultation on the Coordinated Long-Term Operation of the CVP and SWP, partly due to low numbers of Delta Smelt in salvage at CVP and SWP since the initiation of the 2008 BO (USFWS 2019). As a result, the USFWS released the 2019 Biological Opinion which removed the 2008 declaration of jeopardy for Delta Smelt, removed the RPA's under the USFWS 2008 BO, and relaxed additional protective measures to minimize entrainment of Delta Smelt, which would also affect entrainment of Longfin Smelt. In 2020, CDFW took unprecedented action to protect Delta Smelt and Longfin Smelt by not issuing a consistency determination for the 2019 USFWS BO, rather, CDFW through its issuance of Incidental Take Permit No. 2081-2019-066-00 for Long-Term Operation of the State Water Project in the Sacramento San Joaquin Delta implemented more protective measures for both smelt species (CDFW 2020). The 2020 ITP upholds many of the protective measures outlined in the $2008 \mathrm{BO}$ and implements several new measures such as expanded monitoring for Longfin Smelt, additional monitoring for larval fish entrainment at SWP, and the development of a Longfin Smelt science program. Importantly, the ITP states "For the purposes of the ITP, where the terms and conditions in the federal authorization are less protective of the covered species or otherwise confluence with this ITP, the conditions of approval set forth in this ITP shall control." This effectively established different rules for export operations between the CVP and SWP in the south Delta. Despite these new state regulations, unusually high salvage of Longfin Smelt juveniles occurred in 2020 compared to other years since the POD, emphasizing the need to implement the larval entrainment monitoring program under the ITP (Fig. 5). Both the 2019 BO and 2020 ITP are currently under litigation, thus at the time of this writing it remains uncertain how smelt will be managed in the coming years.

The upper San Francisco Estuary is a prime example of the balance between anthropogenic modifications and the protection of natural resources. CESA and FESA protections put in place in the Estuary have provided some legal backing to help protect imperiled species. For Delta Smelt and Longfin Smelt, the implementation of these protections have greatly stimulated research and synthesis, which in turn have greatly expanded our knowledge about both species and the Estuary as a whole, but thus far have failed to protect these smelts from the threat of extinction. The CDFW long-term monitoring datasets have continued in large part thanks to the CESA and FESA listings of both smelt species and other related regulatory needs, and these regulations were in turn brought about because of trends detected in the data collected by the long-term monitoring surveys. These data have also been used to identify population drivers and turning points in the Estuary (Thomson et al. 2010) and have provided the foundation for a wealth of knowledge on a many other species (e.g., Orsi 1999; Baxter et al. 2010; Brown et al. 2014; IEP 2015). There are many competing factors to consider when implementing protections for a species, and in the case of the Estuary, full protection as required under the ESA and CESA is not always possible. Major declines occurred during drought periods, which further challenges recovery.

The opportunity to meet conditions needed for recovery of listed smelt are becoming increasing challenging in the face of climate change and will require continued collaboration among agencies and stakeholders. Multiple agencies are working together to balance the water needs of Californians with the water needs of fish and wildlife in the Estuary, but the resources of the Estuary are stretched thin, leaving the system vulnerable to incom- 
ing stressors (Mahardja et al. 2020), and although protections have been put in place, the abundance of these two species have continued to decline. Given the current status of both smelt species, their short life spans, the changing climate, and the myriad factors that can cause recruitment failure in any given year, recovery of these smelt in the San Francisco Estuary will require management and conservation actions over many generations in order to create environmental conditions that can rebuild population resilience. Accomplishing this will require an unprecedented level of commitment and collaboration among all regulatory and management agencies, water districts, and the public, as well as the continuation and adaptation of current long-term monitoring.

\section{ACKNOWLEDGMENTS}

This review was conducted by staff working on studies in the Interagency Ecological Program for the San Francisco Estuary (IEP) and would not have been possible if not for the long-term monitoring data provided by the IEP. The viewpoints expressed are those of the authors and do not necessarily represent the opinions of the other member agencies of the IEP. We thank the support of L. Damon (CDFW), S. Slater (CDFW), R. Hartman (DWR), and the three anonymous reviewers in the development of this article. Suggestions from reviewers were appreciated as they greatly improved the clarity of the work.

\section{LITERATURE CITED}

Arthur, J. F., M. D. Ball, and S. Y. Baughman. 1996. Summary of federal and state water project environmental impacts on the San Francisco Bay-Delta Estuary, California. Pages 445-495 in J. T. Hollibaugh, editor. San Francisco Bay: The Ecosystem. American Association for the Advancement of Science, San Francisco, CA, USA.

Baxter, R. 1999. Osmeridae. Pages 179-216 in J. Orsi, editor. Report on the 1980-1995 fish, shrimp and crab sampling in the San Francisco Estuary. Interagency Ecological Program for the Sacramento-San Joaquin Estuary Technical Report 63.

Baxter, R., R. Breuer, L. Brown, L. Conrad, F. Feyrer, S. Fong, K. Gehrts, L. Grimaldo, B. Herbold, P. Hrodey, A. Mueller-Solger, T. Sommer, and K. Souza. 2010. Interagency Ecological Program 2010 Pelagic organism decline work plan and synthesis of results through August 2010. Interagency Ecological Program for the San Francisco Estuary.

Blumenshine, S. C., D. M. Lodge, and J. R. Hodgson. 2000. Gradient of fish predation alters body size distributions of lake benthos. Ecology 81:374-386.

Bograd, S. J., D. A. Checkley, Jr, and W. S. Wooster. 2003. CalCOFI: A half century of physical, chemical, and biological research in the California Current System. Deep Sea Research Part II: Topical Studies in Oceanography 50:2349-2353.

Brown, L. R., R. Baxter, G. Castillo, L. Conrad, S. Culberson, G. Erickson, F. Feyrer, S. Fong, K. Gehrts, L. Grimaldo, B. Herbold, J. Kirsch, A. Mueller-Solger, S. Slater, K. Souza, and E. Van Nieuwenhuyse. 2014. Synthesis of studies in the fall low-salinity zone of the San Francisco Estuary, September-December 2011. U.S. Geological Survey Scientific Investigations Report 2014-5041.

Brown, L. R., W. A. Bennett, R. W. Wagner, T. Morgan-King, N. Knowles, F. Feyrer, D. H. Schoellhamer, M. T. Stacey, and M. Dettinger. 2013. Implications for future 
survival of Delta Smelt from four climate change scenarios for the SacramentoSan Joaquin Delta, California. Estuaries and Coasts 36(4):754-774.

Brown, L. R., W. Kimmerer, L. Conrad, S. Lesmeister, and A. Mueller-Solger. 2016. Food webs of the Delta, Suisun Bay, and Suisun Marsh: an update on current understanding and possibilities for management. San Francisco Estuary and Watershed Science 14(3).

Brown, R., S. Greene, P. Coulston, and S. Barrow. 1996. An evaluation of the effectiveness of fish salvage operations at the intake to the California Aqueduct, 1979-1993. Pages 497-518 in J. T. Hollibaugh, editor. San Francisco Bay: The Ecosystem. American Association for the Advancement of Science, San Francisco, CA, USA.

California Department of Fish and Game (CDFG). 2008. Report to the Fish and Game Commission. A Status Review of the Threatened Delta Smelt (Hypomesus transpacificus) in California. California Natural Resources Agency, Sacramento, CA, USA.

California Department of Fish and Game (CDFG). 2009. California Endangered Species Act Incidental Take Permit No. 2081-2009-001-03 for the Department of Water Resources California State Water Project Delta Facilities and Operations, Yountville, CA, USA

California Department of Fish and Wildlife (CDFW). 2020. California Endangered Species Act Incidental Take Permit No. 2081-2019-066-00 for the California Department of Water Resources Long-Term Operation of the State Water Project in the Sacramento-San Joaquin Delta. Sacramento, CA, USA.

California Resources Agency, California Department of Water Resources, and California Department of Fish and Game. 2005. Delta Smelt Action Plan. Available from: https://www.baydeltalive.com/assets/application/pdf/10-19-05DeltaSmeltActionPlan.pdf

California Resources Agency, California Department of Water Resources, and California Department of Fish and Game. 2007. Pelagic Fish Action Plan. Available from: https://www.waterboards.ca.gov/waterrights/water_issues/programs/bay_delta/ pelagic_organism/docs/dwr_030507report.pdf

Castillo, G. C., L. J. Damon, and J. A. Hobbs. 2018. Community patterns and environmental associations for pelagic fishes in a highly modified estuary. Marine and Coastal Fisheries: Dynamics, Management, and Ecosystem Science 10:508-524.

Chadwick, H. K., D. E. Stevens, and L. W. Miller. 1977. Some factors regulating the striped bass population in the Sacramento-San Joaquin Estuary, California. Pages 18-35 in W. Van Winkle, editor. Proceedings of the Conference on Assessing the Effects of Power-Plant-Induced Mortality on Fish Populations. Pergamon Press Inc., Oxford, UK.

Cloern, J. E., and A. D. Jassby. 2012. Drivers of change in estuarine-coastal ecosystems: discoveries from four decades of study in San Francisco Bay. Review of Geophysics 50(4).

Contreras, D., V. Afentoulis, K. Hieb, R. Baxter, and S. Slater. 2011. 2010 Status and trends report for pelagic fishes of the Upper Francisco Estuary. Interagency Ecological Program for the San Francisco Estuary Newsletter 24(2):27-37.

Erkkila, L. F., J. W. Moffett, O. B. Cope, B. R. Smith, and R. S. Nelson. 1950. SacramentoSan Joaquin Delta fishery resources: effects of Tracy Pumping Plant and Delta 
cross channel. U.S. Fish and Wildlife Service Special Scientific Report 56:1-109.

Feyrer, F., B. Herbold, S. A. Matern, and P. B. Moyle. 2003. Dietary shifts in a stressed fish assemblage: consequences of a bivalve invasion in the San Francisco Estuary. Environmental Biology of Fishes 67(3):277-288.

Flow Alteration - Management, Analysis, and Synthesis Team (FLOAT-MAST). 2020. Synthesis of data and studies relating to Delta Smelt biology in the San Francisco Estuary, emphasizing water year 2017. IEP Technical Report. Interagency Ecological Program, Sacramento, CA, USA.

Grimaldo, L. F., T. Sommer, N. Van Ark, G. Jones, E. Holland, P. B. Moyle, B. Herbold, and P. Smith. 2009. Factors affecting fish entrainment into massive water diversions in a tidal freshwater estuary: Can fish losses be managed? North American Journal of Fisheries Management 29(5):1253-1270.

Grimaldo, L., J. Burns, R. E. Miller, A. Kalmbach, A. Smith, J. Hassrick, and C. Brennan. 2020. Forage fish larvae distribution and habitat use during contrasting years of low and high freshwater flow in the San Francisco Estuary. San Francisco Estuary and Watershed Science 18(3).

Hammock, B. G., J. A. Hobbs, S. B. Slater, S. Acuña, and S. J. The. 2015. Contaminant and food limitation stress in an endangered estuarine fish. Science of the Total Environment 532:316-326.

Herrgesell, P. L. 2012. A historical perspective of the Interagency Ecological Program: Bridging multi-agency studies into ecological understanding of the Sacramento-San Joaquin Dela and Estuary for 40 Years. Interagency Ecological Program Report. Available from: https://cawaterlibrary.net/wp-content/uploads/2017/06/ Herrgesell_IEP_Report_FINAL.pdf

Hobbs, J. A., L. S. Lewis, M. Willmes, C. Denney, and E. Bush. 2019. Complex life histories discovered in a critically endangered fish. Scientific Reports 9(1):1-12.

Honey, K., R. Baxter, Z. Hymanson, T. Sommer, M. Gingras, and P. Cadrett. 2004. IEP Long-term Fish Monitoring Program Element Review. Interagency Ecological Program for the San Francisco Bay/Delta Estuary. Available from: https://www. academia.edu/507408/IEP_long_term_fish_monitoring_program_element_review

Hughes, B. B., R. Beas-Luna, A. K. Barner, K. Brewitt, D. R. Brumbaugh, E. B. CernyChipman, S. L. Close, K. E. Coblentz, K. L. De Nesnera, S. T. Drobnitch, and J. D. Figurski. 2017. Long-term studies contribute disproportionately to ecology and policy. BioScience 67(3):271-281.

Hutton, P. H., J. S. Rath, and S. B. Roy. 2017a. Freshwater flow to the San Francisco Bay-Delta estuary over nine decades (Part 1): trend evaluation. Hydrological Processes 31(14):2500-2515.

Hutton, P. H., J. S. Rath, and B. B. Roy. 2017b. Freshwater flow to the San Francisco Bay-Delta estuary over nine decades (Part 2): change attribution. Hydrological Processes 31(14):2516-2529.

Interagency Ecological Program Management, Analysis and Synthesis Team (IEPMAST). 2015. An updated conceptual model of Delta Smelt biology: our evolving understanding of an estuarine fish. Interagency Ecological Program for the Sacramento-San Joaquin Estuary Technical Report 90. Available from: https:// www.researchgate.net/publication/273379257_An_updated_conceptual_model_ 
of_Delta_Smelt_biology_our_evolving_understanding_of_an_estuarine_fish

Kimmerer, W. J. 2002. Effects of freshwater flow on abundance of estuarine organisms: physical effects or trophic linkages? Marine Ecology Progress Series 243:39-55. Kimmerer, W. J. 2008. Losses of Sacramento River Chinook Salmon and Delta Smelt to entrainment in water diversions in the Sacramento-San Joaquin Delta. San Francisco Estuary and Watershed Science 6(2).

Kimmerer, W. J., J. H. Cowan, L. W. Miller, and K. A. Rose. 2001. Analysis of an estuarine striped bass population: effects of environmental conditions during early life. Estuaries 24(4):557-575.

Kimmerer, W. J., E. Gartside, and J. J. Orsi. 1994. Predation by an introduced clam as the likely cause of substantial declines in zooplankton of San Francisco Bay. Marine Ecology Progress Series 113:81-93.

Lewis, L. S., M. Willmes, A. Barros, P. K. Crain, and J. A. Hobbs. 2020. Newly discovered spawning and recruitment of threatened Longfin Smelt in restored and underexplored tidal wetlands. Ecology 101(1):e2868.

Likens, G. E., editor. 2012. Long-term Studies in Ecology. Springer, New York, NY, USA. Lindenmayer, D. B., G. E. Likens, A. Anderson, D. Bowman, C. M. Bull, E. Burns, C. R. Dickman, A. A. Hoffman, D. A. Keith, M. J. Liddell, A. J. Lowe, D. J. Metcalfe, S. R. Phinn, J. Russell-Smith, N. Thurgate, and G. M. Wardle. 2012. Value of longterm ecological studies. Austral Ecology 37:745-757.

Mac Nally, R., C. Albano, and E. Fleishman. 2014. A scrutiny of the evidence for pressure-induced state shifts in estuarine and nearshore ecosystems. Austral Ecology 39(8):898-906.

Mahardja, B., V. Tobias, S. Khanna, L. Mitchell, P. Lehman, T. Sommer, L. Brown, S. Culberson, and J. L. Conrad. 2020. Resistance and resilience of pelagic and littoral fishes to drought in the San Francisco Estuary. Ecological Applications 31(2): 02243.

McAllister, D. E. 1963. A revision of the smelt family, Osmeridae. Bulletin National Museum of Canada 191:1-53.

Mitchell, L., K. Newman, and R. Baxter. 2019. Estimating the size selectivity of fishing trawls for a short-lived fish species. San Francisco Estuary and Watershed Science $17(1)$.

Morinaka, J. 2013. A history of the operational and structural changes to the John E. Skinner Delta Fish Protective Facility from 1968 to 2010. Interagency Ecological Program for the San Francisco Bay/Delta Estuary. Technical Report 85.

Moyle, P. B. 2002. Inland Fishes of California. University of California Press, Berkeley, CA, USA.

Moyle, P. B., L. R. Brown, J. R. Durand, and J. A. Hobbs. 2016. Delta Smelt: life history and decline of a once abundant species in the San Francisco Estuary. San Francisco Estuary and Watershed Science 14(2).

Moyle, P. B., B. Herbold, D. E. Stevens, and L. W. Miller. 1992. Life-history and status of Delta Smelt in the Sacramento-San-Joaquin Estuary, California. Transactions of the American Fisheries Society 121:67-77.

Orsi, J., editor. 1999. Report on the 1980-1995 fish, shrimp and crab sampling in the San Francisco Estuary, California, The Interagency Ecological Program for the Sacramento-San Joaquin Estuary. Technical Report 63. 
Reis, G. J., J. K. Howard, and J. A. Rosenfield. 2019. Clarifying effects of environmental protections on freshwater flows to - and Water Exports from-the San Francisco Bay Estuary. San Francisco Estuary and Watershed Science17(1).

Rosenfield, J. A., and R. D. Baxter. 2007. Population dynamics and distribution patterns of Longfin Smelt in the San Francisco Estuary. Transactions of the American Fisheries Society. 136:1577-1592.

San Francisco Estuary Institute-Aquatic Science Center (SFEI-ASC). 2014. A delta transformed: ecological functions, spatial metrics, and landscape change in the Sacramento-San Joaquin Delta. Prepared for the California Department of Fish and Wildlife Ecosystem Restoration Program. A Report of SFEI-ASC's Resilient Landscapes Program, Publication \#729, San Francisco Estuary Institute-Aquatic Sciance Center, Richmond, CA, USA.

Smith, W. E. 2019. Integration of transport, survival, and sampling efficiency in a model of South Delta entrainment. San Francisco Estuary and Watershed Science 17(4).

Smith, W. E., K. B. Newman, and L. Mitchell. 2020. A Bayesian hierarchical model of postlarval delta smelt entrainment: integrating transport, length composition, and sampling efficiency in estimates of loss. Canadian Journal of Fisheries and Aquatic Sciences 77(5):789-813.

Sommer, T., C. Armor, R. Baxter, R. Breuer, L. Brown, M. Chotkowski, S. Culberson, F. Feyrer, M. Gingras, B. Herbold, W. Kimmerer, A. Mueller-Solger, M. Nobriga, and K. Souza. 2007. The collapse of pelagic fishes in the Upper San Francisco Estuary. Fisheries 32(6):270-277.

Souza, K. 2002. Revision of the California Department of Fish and Game's Spring Midwater Trawl and results of the 2002 Spring Kodiak Trawl. Interagency Ecological Program Newsletter 153:44-47.

State Water Resources Control Board. (SWRCB) 1999. Water Right Decision 1641 in the Matter of: Implementation of Water Quality Objectives for the San Francisco Bay/Sacramento-San Joaquin Delta Estuary; A Petition to Change Points of Diversion of the Central Valley Project and State Water Project in the Southern Delta; and A Petitio to Change Places of Use and Purpose of Use of the Central Valley Project.

Stevens, D. E., D. W. Kohlhorst, L. W. Miller, and D. W. Kelley. 1985. The decline of Striped Bass in the Sacramento-San Joaquin Estuary, California. Transactions of the American Fisheries Society 114:12-30.

Stevens, D. E., L. W. Miller, and B. C. Bolster. 1990. A Status Review of the Delta Smelt (Hypomesus transpacificus) in California. Candidate Status Report 90-2. California Department of Fish and Game, Sacramento, CA, USA.

Sweetnam, D. A. 1994. Preliminary results of the Interagency Ecological Program's Delta Smelt net evaluation study. Memorandum from the California Department of Fish and Game to Hanson Environmental and the Department of Water Resources. Dated October 4, 1994.

Sweetnam, D. A., and D. E. Stevens. 1993. Report to the Fish and Game Commission: a status review of the Delta Smelt (Hypomesus transpacificus) in California. California Natural Resources Agency, Sacramento, CA, USA.

Teh, S. J., A. A. Shultz, W. R. Duarte, S. Acuña, D. M. Barnard, R. D. Baxter, P. A. T. Garcia, and B. G. Hammock. 2020. Histopathological assessment of seven year- 
classes of Delta Smelt. Science of The Total Environment. 726(138333).

Tempel, T. 2017. Evaluation of adding index stations in calculating the 20-mm survey Delta Smelt abundance index. Interagency Ecological Program Newsletter 30(1):21-23.

Thomson, J. R., W. J. Kimmerer, L. R. Brown, K. B. Newman, R. Mac Nally, W. A. Bennett, F. Feyrer, and E. Fleishman. 2010. Bayesian change point analysis of abundance trends for pelagic fishes in the upper San Francisco Estuary. Ecological Applications 20(5):1431-1448.

Turner, J. L., and H. K. Chadwick. 1972. Distribution and abundance of young-of-the-year Striped Bass, Morone saxatilis, in relation to river flow in the Sacramento-San Joaquin estuary. Transactions of the American Fisheries Society 101:442-452.

U.S. Fish and Wildlife Service (USFWS). 1993. Endangered and Threatened Wildlife and Plants; Determination of Threatened Status for the Delta Smelt. Federal Register 58(42):12854-12864.

U.S. Fish and Wildlife Service (USFWS). 1995. Formal Consultation and Conference on Effects of Long-term Operation of the Central Valley Project and State Water Project on the Threatened Delta Smelt, Delta Smelt Critical Habitat, and Proposed Threatened Splittail. Region 8, Sacramento, CA, USA.

U.S. Fish and Wildlife Service (USFWS). 1996. Recovery Plan for the Sacramento-San Joaquin Delta Native Fishes. Region 1, Portland, OR, USA.

U.S. Fish and Wildlife Service (USFWS). 2008. Formal Endangered Species Act consultation on the proposed coordinated operations of the Central Valley Project (CVP) and State Water Project (SWP) Sacramento, CA, USA. Available from: http:// deltacouncil.ca.gov/docs/ background-materials-delta-science-program-ocap/ formal-endangered-species-act-consultation

U. S. Fish and Wildlife Service (USFWS). 2009. Endangered and Threatened Wildlife and Plants; 12-Month Finding of a Petition to List the San Francisco Bay-Delta Population of the Longfin Smelt (Spirinchus thaleichthys) as Endangered. Federal Register 74(67):16169-16175.

U. S. Fish and Wildlife Service (USFWS). 2010. Endangered and Threatened Wildlife and Plants; 12-Month Finding of a Petition to Reclassify the Delta Smelt from Threatened to Endangered Throughout its Range. Federal Register 75(66):17667-17680.

U. S. Fish and Wildlife Service (USFWS). 2012. Endangered and Threatened Wildlife and Plants; 12-Month Finding on a Petition to List the San Francisco Bay-Delta Population of the Longfin Smelt as Endangered or Threatened. Federal Register 77(63):19756-19797.

U.S. Fish and Wildlife Service (USFWS). 2019. Biological Opinion of the Coordinated Operations of the Central Valley Project and State Water Project. Sacramento, CA, USA. Available from: https://www.fws.gov/sfbaydelta/cvp-swp/documents/10182019_ROC_BO_final.pdf

Winder, M., and A. D. Jassby. 2011. Shifts in zooplankton community structure: Implications for food-web processes in the upper San Francisco Estuary. Estuaries and Coasts 34(4):675-690.

Wolfe, D. A., M. A. Champ, D. A. Flemer, and A. J. Mearns. 1987. Long-term biological data sets: their role in research, monitoring, and management of estuarine and coastal marine systems. Estuaries 10(3):181.

White, J., and R. D. Baxter. In review. Incorporating expanded sampling into an alternative 
abundance index for the Fall Midwater Trawl Survey. Submitted to San Francisco Estuary and Watershed Science.

Submitted 4 November 2020

Accepted 2 December 2020

Associate Editor was M. Fish 